\title{
Activity of the Lupane Isolated from Combretum leprosum against Leishmania amazonensis Promastigotes
}

\author{
Carolina B. G. Teles, ${ }^{a}$ Leandro S. Moreira, ${ }^{b}$ Alexandre de A. E. Silva, ${ }^{a, b}$ Valdir A. Facundo, ${ }^{b}$ \\ Juliana P. Zuliani, ${ }^{a, b}$ Rodrigo G. Stábeli, ${ }^{a, c}$ and Izaltina Silva-Jardim ${ }^{*, a}$
} ${ }^{a}$ Instituto de Pesquisas em Patologias Tropicais de Rondônia-IPEPATRO, Rua da Beira, 7671,
BR 364, km 3,5, 76812-245 Porto Velho-RO, Brazil

${ }^{b}$ Universidade Federal de Rondônia, BR 364, km 9,5, 76800-000 Porto Velho-RO, Brazil

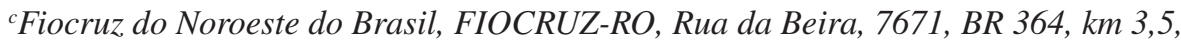
76812-245 Porto Velho-RO, Brazil

\begin{abstract}
O presente trabalho descreve a atividade do extrato etanólico (EE) dos frutos de Combretum

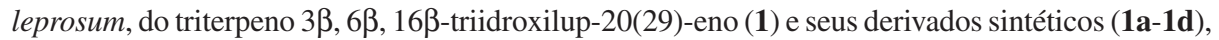
sobre promastigotas de Leishmania amazonensis. O EE apresentou atividade leishmanicida e o valor de $\mathrm{IC}_{50}$ foi de $24,8 \mu \mathrm{g} \mathrm{mL} \mathrm{m}^{-1}$. Já o triterpeno $3 \beta, 6 \beta, 16 \beta$-trihidroxilup-20(29)-eno (1), na concentração de $5,0 \mu \mathrm{g} \mathrm{mL} L^{-1}$, apresentou uma potente ação inibitória sobre a proliferação das promastigotas $\left(\mathrm{IC}_{50}=3,3 \mu \mathrm{g} \mathrm{mL^{-1 }}\right)$. Entre os derivados sintéticos, apenas $\mathbf{1 b}$ e $\mathbf{1 d}$ apresentaram atividade contra as promastigotas $\left(\mathrm{IC}_{50}=3,48 \mu \mathrm{g} \mathrm{mL}-1\right.$ e $5,8 \mu \mathrm{g} \mathrm{mL} \mathrm{m}^{-1}$, respectivamente). Por outro lado, o derivado sintético 1a não apresentou atividade sobre as promastigotas de L. amazonensis. O EE, (1) e os derivados sintéticos 1a-1d não apresentaram efeito citotóxico sobre macrófagos peritoneais de camundongos. Estes resultados fornecem evidencias de que o extrato etanólico e o lupano isolado de C. leprosum possui atividade contra promastigotas de L. amazonensis, podendo ser utilizados como ferramentas no estudo de novas drogas leishmanicidas.
\end{abstract}

This paper describes the activity of the ethanolic extract (EE), obtained from the fruits of Combretum leprosum, the triterpene $3 \beta, 6 \beta, 16 \beta$-trihydroxylup-20(29)-ene (1) and its synthetic derivatives 1a-1d on Leishmania amazonensis promastigotes. The EE displayed leishmanicidal activity and the $\mathrm{IC}_{50}$ was $24.8 \mu \mathrm{g} \mathrm{mL}^{-1}$. However, the triterpene $3 \beta, 6 \beta$, 16 $\beta$-trihydroxylup-20(29)ene (1), at a concentration of $5.0 \mu \mathrm{g} \mathrm{mL} \mathrm{m}^{-1}$, showed a potent inhibitory activity on promastigotes proliferation $\left(\mathrm{IC}_{50}=3.3 \mu \mathrm{g} \mathrm{mL}^{-1}\right)$. Among the synthetic derivatives, only (1b) and (1d) were active against promastigotes $\left(\mathrm{IC}_{50}=3.48 \mu \mathrm{g} \mathrm{mL}^{-1}\right.$ and $5.8 \mu \mathrm{g} \mathrm{mL}^{-1}$, respectively). Moreover, the synthetic derivative 1a showed no activity on promastigotes of L. amazonensis. EE, (1) and the synthetic derivatives 1a-1d showed no cytotoxic effect on mice peritoneal macrophages. These results provide evidence that the ethanolic extract and the lupane isolated from $C$. leprosum was active against promastigotes of L. amazonensis, and may be used as a tool in the studies of new antileishmanial drugs.

Keywords: promastigotes, Leishmania amazonensis, Combretum leprosum, triterpene, synthetic derivatives

\section{Introduction}

Leishmania, a protozoan parasite belonging to the family Trypanosomatidae, causes a broad spectrum of diseases, collectively known as leishmaniasis. Such conditions occur predominantly in tropical and subtropical regions. Approximately 350 million people live in areas of active Leishmania transmission, with 12 million people

*e-mail: izaltina.jardim@pq.cnpq.br being directly affected by leishmaniasis in Africa, Asia, Europe and Americas. ${ }^{1}$

Leishmania parasites have a complex life cycle that involves Phlebotomine sandfly vectors and mammalian hosts, with the amastigotes being within the phagolysosome of macrophages and the promastigotes in the vector's midgut. $^{2}$

The clinical manifestations of leishmaniasis are often divided in cutaneous, diffuse cutaneous, mucocutaneous and visceral leishmaniasis. ${ }^{3,4}$ Cutaneous leishmaniasis can 
be spontaneously healed after a few months, or, depending on the Leishmania species, develop into diffuse cutaneous, relapsing cutaneous or mucocutaneous leishmaniasis. Visceral leishmaniasis, if untreated, leads to death in most patients. ${ }^{5,6}$ This disease causes considerable morbidity and severe face-disfigurement lesions on the affected people.

Nowadays, chemotherapy for leishmaniasis is still based on pentavalent antimonials (Glucantime and Pentostam), diamines (Pentamidine) and antifungal polyene (Amphotericin B). These are only a few of the drugs available since 1940. Unfortunately, they are generally toxic, expensive, share a tendency to generate resistance and require long-term treatments, which would make the conclusion complicated. ${ }^{7}$ Therefore, there is a great and urgent need to develop new, more effective and safer drugs for leishmaniasis control.

Plants provide a potential alternative source of therapeutic compounds in the search for new agents for leishmaniasis and others protozoan diseases treatment. ${ }^{8-10}$ They are often used by traditional communities, and, based on documented history of folk usage, many compounds have been isolated. Chalcones, alkaloids, triterpenes, and acetogenins have promising activity against protozoan parasites. ${ }^{11-14}$ Plants of the Combretaceae family are widely sold in the traditionalmedicine markets in southern Africa. ${ }^{15}$ Several authors have demonstrated that some extracts or purified compounds of the Combretum species have a broad spectrum of biological activities ${ }^{16-19}$ including antiviral, ${ }^{15,20}$ antibacterial, ${ }^{20,21}$ antiprotozoal, ${ }^{22,23}$ anticancer, ${ }^{24-26}$ analgesic, ${ }^{27}$ anti-inflamatory and hepatoprotective. ${ }^{28}$ The usage of Combretum genera in folk medicine includes the treatment of a broad range of diseases, such as abdominal pain, back pain, cough, cold, conjunctivitis, diarrhea, dysmenorrhea, earache, fever, headache, fighting worms, infertility in women, leprosy, pneumonia, scorpion stings and snake bite. ${ }^{16}$

Combretum leprosum Mart., a member of the Combretaceae family, from northern Brazil, popularly known as "mufumbo" or "mofumbo" or "cipoaba" is used in folk medicine to treat haemorrhages and as a sedative. ${ }^{27}$ In order to evaluated the antileishmanial activity of Combretum leprosum, ethanolic extract (EE) and $3 \beta, 6 \beta, 16 \beta$-trihydroxylup-20(29)-ene (1) isolated from the fruit, and four synthetic derivatives 1a-1d were investigated in L. amazonensis promastigotes.

\section{Experimental}

\section{Parasites}

Promastigotes of Leishmania (Leishmania) amazonensis PH8 strain (IFLA/BR/67/PH8) were axenically cultured at
$23{ }^{\circ} \mathrm{C}$ in RPMI 1640, supplemented with $10 \%$ inactivated fetal bovine serum (FBS), $20 \mathrm{mmol} \mathrm{L}^{-1}$ Hepes (N-2hydroxyethylpiperazine-N'-2-ethanesulfonic acid), and $50 \mu \mathrm{g} \mathrm{mL}^{-1}$ of gentamycin. On the $5^{\text {th }}$ day of culture (stationary phase of growth), promastigotes were harvested for the in vitro assays.

\section{Plant material}

Botanical material was colleted in May 2001 in Viçosa, Ceará State, Brazil, and identified by Dr. Afrânio Fernandes (Federal University of Ceará, Fortaleza) as Combretum leprosum Mart. A voucher specimen was deposited (No. 12446) in the Herbarium Prisco Bezerra, Biology Department, Federal University of Ceará, Brazil.

\section{Instrumentation and chromatography}

Silica gel (Merck 70-230 mesh) was used for all column chromatographies and solvents were redistilled prior to use. ${ }^{1} \mathrm{H}$ and ${ }^{13} \mathrm{C}$ NMR spectra $1 \mathrm{D}$ and $2 \mathrm{D}$ dimensions, were recorded at 300 and $75 \mathrm{MHz}$, respectively, using $\mathrm{CDCl}_{3}$ or pyridine- $d_{5}$, using TMS as internal standard; EIMS: Finnigan 3200 GC-MS instrument, electron impact mode, $70 \mathrm{eV}$. UV and IR spectra were obtained with a PerkinElmer PC FT-IR apparatus.

\section{Ethanolic extract (EE) obtention, compound 1 isolation and purification}

Dried fruits $(2.7 \mathrm{~kg})$ were powdered and then extracted with ethanol $(5 \mathrm{~L})$, being stirred and macerated at room temperature for approximately $24 \mathrm{~h}$. This procedure was repeated three times. The solvent was fully evaporated under reduced pressure and the EE (58.3 g) was concentrated and stored at $-20{ }^{\circ} \mathrm{C}$ prior to use. Part of the EE (32.0 g) was submitted to coarse chromatography over silica gel $(600 \mathrm{~g})$ using hexane, $\mathrm{CHCl}_{3}$, EtOAc and $\mathrm{MeOH}$ as eluents. The fraction eluted with $\mathrm{CHCl}_{3}$ was chromatographed on a silica gel column and was eluted with hexane-EtOAc, in increasing polarity. The fractions 27-30, eluted with hexane:EtOAc (30:70), were combined on the basis of thin layer chromatography (TLC) analysis and the presence of a white precipitate was observed, which after recrystallization from ethanol, was identified as $\mathbf{1}(2.37 \mathrm{~g}){ }^{29}$

\section{Preparation of the synthetic derivatives $\mathbf{1 a - 1 d}$}

The derivatives 1a-1d were prepared in accordance with Facundo et al. ${ }^{29}$ 


\section{Derivative 1 a}

$0.54 \mathrm{mmol}$ of $\mathbf{1}$ was dissolved in acetic anhydride $\left(5.0 \mathrm{~cm}^{3}\right)$ and pyridine $\left(1.0 \mathrm{~cm}^{3}\right)$. After $24 \mathrm{~h}$, the material was poured over ice and the resulting mixture extracted with ethyl ether. The ethereal solution was washed with $3 \%$ aqueous $\mathrm{HCl}$ to eliminate the presence of pyridine. After solvent distillation and silica gel column purification, it yielded $0.34 \mathrm{mmol}$ of the acetylated derivative $\mathbf{1 a}$.

\section{Derivative $\mathbf{1 b}$}

$0.65 \mathrm{mmol}$ of $\mathbf{1}$ was dissolved in dichloromethane $\left(170 \mathrm{~cm}^{3}\right)$ and treated with pyridinium chlorochromate $(1.53 \mathrm{mmol}$ ) for $2 \mathrm{~h}$, under agitation, at room temperature. The mixture was filtered and extracted with ethyl ether solvent evaporation and silica chromatographic column purification, yielding $0.45 \mathrm{mmol}$ of the oxidized product $1 b$.

\section{Derivative $1 c$}

$0.22 \mathrm{mmol}$ of $\mathbf{1 a}$ dissolved in dichloromethane $\left(100 \mathrm{~cm}^{3}\right)$ was treated with pyridinium chlorochromate $(0.65 \mathrm{mmol})$ for $2 \mathrm{~h}$, under agitation. The mixture was filtered and extracted with diethyl ether. After solvent distillation and silica gel column purification, the crude product yielded 1c $(0.17 \mathrm{mmol})$.

\section{Derivative $1 d$}

$0.10 \mathrm{mmol}$ of $1 \mathrm{c}$ was dissolved in a saturated solution of methanol and hydroxide potassium. The mixture was kept under reflux for $3 \mathrm{~h}$ at $70{ }^{\circ} \mathrm{C}$. After organic solvent evaporation, $70 \mathrm{~cm}^{3}$ of distilled water was added and the organic part was extracted with ethyl ether. After solvent evaporation and silica chromatographic column purification $0.08 \mathrm{mmol}$ of $\mathbf{1 d}$ was obtained.

The structure of compound $\mathbf{1}$ and its synthetic derivatives (1a-d) are shown in Figure 1. The spectroscopic data are presented in the Supplementary Information.

\section{Antileishmanial activity}

The antiparasitic activity of ethanolic extract (EE), isolated triterpene $\mathbf{1}$ and synthetic derivatives (1a, 1b, 1d) from $C$. leprosum were evaluated against Leishmania amazonensis promastigote forms. The EE, $\mathbf{1}$ and the synthetic derivatives were dissolved in ethanol (less $1 \%$ ). Promastigotes $\left(5 \times 10^{5}\right.$ per well $)$ in 24 -well were incubated in RPMI-1640 culture medium in the absence or in the presence of 1,2 and $5 \mu \mathrm{g}$ per $\mathrm{mL}$ of triterpenes and 12.5, 25,50 and $100 \mu \mathrm{g}$ per $\mathrm{mL}$ of the EE during 5 days at $23{ }^{\circ} \mathrm{C}$. The number of living promastigotes was scored in the presence of erythrosin B. The results were expressed as the concentrations inhibiting parasite growth by $50 \%\left(\mathrm{IC}_{50}\right)$ after a 5 days incubation period. Pentamidine was used as antileishmanial reference compound. ${ }^{30}$

\section{Toxicity on macrophages}

Cell viability was assessed using a modified MTT assay. ${ }^{31}$ Briefly, elicited peritoneal mice macrophages $\left(1 \times 10^{5}\right.$ cells per well) were seeded in a 96-well plate and

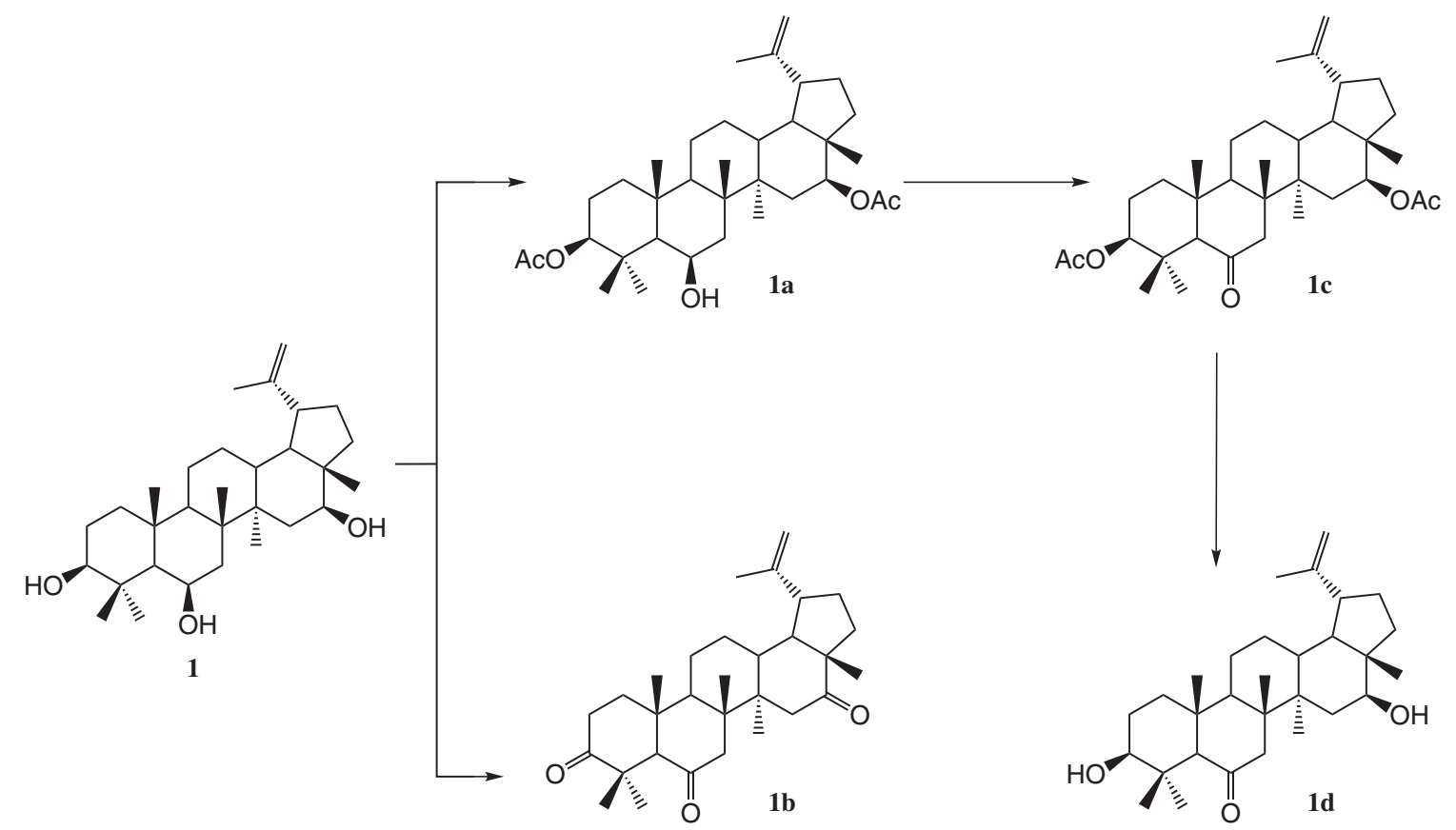

Figure 1. Natural triterpene $\mathbf{1}$ and synthetic derivatives 1a-1d. 
treated with $25 \mu \mathrm{g} \mathrm{mL}^{-1}$ of $\mathrm{EE}$ and $5 \mu \mathrm{g} \mathrm{mL}^{-1}$ of triterpenes. After $24 \mathrm{~h}, 10 \mu \mathrm{L}$ of a MTT solution $\left(5 \mathrm{mg} \mathrm{mL}^{-1}\right.$ in phosphate buffered saline) was added to each well and furtherly incubated for $2 \mathrm{~h}$ at $37^{\circ} \mathrm{C}$. Subsequently, $100 \mu \mathrm{L}$ of dimethylsulfoxide (DMSO) was added to each well to solubilize any deposited formazan and the optical density (OD) of each well was measured at $540 \mathrm{~nm}$.

\section{Statistical analysis}

The inhibitory concentrations (ICs) were calculated by Probit Analysis using the program Minitab 14 (Minitab Inc). The statistical significance of group differences was evaluated using ANOVA and comparisons by StudentNewman-Keuls by the program SigmaStat (SPSS Inc, 1992-1997).

\section{Results and Discussion}

The pharmacological properties of Combretum leprosum have not been characterized up to this moment in details. Some studies had shown a promising potential for antinociceptive, anti-inflammatory, and antiulcerogenic activities. ${ }^{32}$ The arjunolic acid, isolated from roots and flowers of $C$. leprosum, displayed anti-inflammatory, antinociceptive and anticholinesterasic activities. ${ }^{33}$

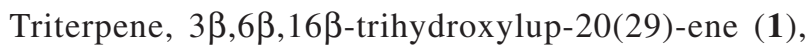
isolated from flowers, showed antinociceptive activity. ${ }^{34}$ In the present work we have shown an anti-leishmanicidal effect that had not been explored for this species yet.

The ethanolic extract (EE) of fruits of C. leprosum was tested in vitro against the promastigote forms of L. amazonensis. Quantifying Leishmania promastigote populational growth is involved in a number of investigations such as drug-efficacy testing and vaccine candidates. ${ }^{35} \mathrm{In}$ such studies, the promastigote stage is most oftenly used once the promastigote is the infective form of the parasite and the proliferation capacity of a strain plays a key role in its infectivity potential. ${ }^{36}$

The EE showed an inhibitory activity, interfering in the promastigotes growth. A significant leishmanicidal effect was evident after 5 days of culture (Table 1). Promastigotes treated with $100 \mu \mathrm{g} \mathrm{mL}^{-1}$ of the EE or pentamidine died after $24 \mathrm{~h}$ of treatment. In all concentrations of EE (12.5-100 $\left.\mu \mathrm{g} \mathrm{mL}^{-1}\right)$ studied, there was a significant difference in the growth of treated parasites compared to controls, not treated with the extract and treated with ethanol $(\mathrm{F}=318.6 ; \mathrm{P}<0.001)$. Promastigotes incubated with $1 \%(\mathrm{v} / \mathrm{v})$ ethanol (the concentration necessary to dissolve the highest extract concentration used in the test) showed growth rates equivalent to the control cultures, indicating that the EE solvent was not toxic to the parasite.

The L. amazonensis promastigotes growth curve in the presence or absence of EE is shown in Figure 2. On the $5^{\text {th }}$ day of culture the promastigotes treated with the EE $\left(25 \mu \mathrm{g} \mathrm{mL}^{-1}\right.$ and $\left.50 \mu \mathrm{g} \mathrm{mL}^{-1}\right)$ showed a decrease in the parasite growth around $80 \%$ and $93 \%$, respectively, compared with control or control treated with ethanol (Figure 2). The estimated $\mathrm{IC}_{50}$ of $\mathrm{EE}$ for L. amazonensis promastigotes was $24.8 \mu \mathrm{g} \mathrm{mL}^{-1}$.

Table 1. Growth inhibition of L. amazonensis cultures by the ethanolic extract (EE) of C. leprosum Mart. in vitro after five days

\begin{tabular}{lc}
\hline Drug & Promastigotes $\times 10^{5}$ \\
\hline Control $(\mathrm{C})$ & $162.1+3.1^{(\mathrm{a})}$ \\
EtOH & $138.2+3.1^{\text {(b) }}$ \\
EE $12.5 \mu \mathrm{g} \mathrm{mL}^{-1}$ & $113.2+3.4^{(\mathrm{c})}$ \\
EE $25 \mu \mathrm{gLL}^{-1}$ & $81.0+2.9^{(\mathrm{d})}$ \\
EE $50 \mu \mathrm{g} \mathrm{mL}^{-1}$ & $22.6+1.9^{(\mathrm{e})}$ \\
\hline
\end{tabular}

One-way ANOVA, Student-Newman-Keuls (comparisons), $\mathrm{n}=8$ (mean \pm $\mathrm{SE})$. Different letters $(\mathrm{a}, \mathrm{b}, \mathrm{c}, \mathrm{d}, \mathrm{e})$ indicate significant $(\mathrm{P}<0.05)$ differences in a column. EE $100 \mu \mathrm{g} \mathrm{mL}^{-1}$ and Pentamidine killed all L. amazonesis promastigotes in culture after 5 days.

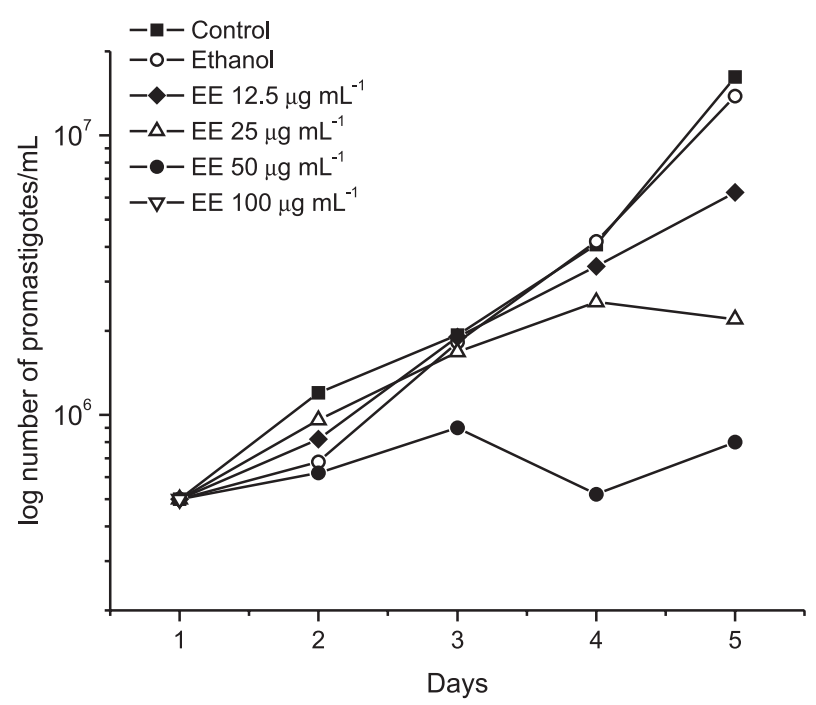

Figure 2. In vitro effect of ethanolic extract of C. leprosum fruits on parasite growth. Representative growth curve of L. amazonensis promastigotes. Promastigotes forms were incubated with a range of EE concentrations during 5 days at $24^{\circ} \mathrm{C}$. The promastigote growth was scored by counting of the viable parasites daily. The data shown is representative of at least five independent experiments.

Phytochemical studies carried out with some species of the genus Combretum indicated the presence of many classes of constituents, including triterpenes, flavonoids, lignans, non-protein amino acids, among others. ${ }^{29,37,38} \mathrm{McGaw}$ et al. ${ }^{16}$ using extracts of 20 species of Combretum, have shown that some of these, such as C. apiculatum, C. imberbe and 
C. molle, present antiinflammatory activity; others, such as $C$. hereroense and $C$. paniculatum have antihelmint and antischistosoma activity, respectively. C. molle also has activity against Trypanosoma brucei rhodesiense and Plasmodium falciparum. ${ }^{39}$ Other Combretum species are capable of causing damages to the DNA of bacteria, such as $C$. apiculatum, $C$. mossambicense and $C$. hereroense. C. fragrans, C. padoides and C. erythrophyllum have antimicrobial activity against Gram-positive and Gramnegative bacteria ${ }^{21,40,41}$ and C. micranthum have antiviral activity against herpes simplex virus types 1 and $2 .{ }^{42}$

In order to investigate the role of $3 \beta, 6 \beta, 16 \beta$ trihydroxylup-20(29)-ene (1), a lupane triterpene isolated from fruits of C. leprosum, we examined the effect of this compound in the L. amazonensis promastigotes growth. Various concentrations of this compound were used and the number of viable cells was scored every $24 \mathrm{~h}$ for up to
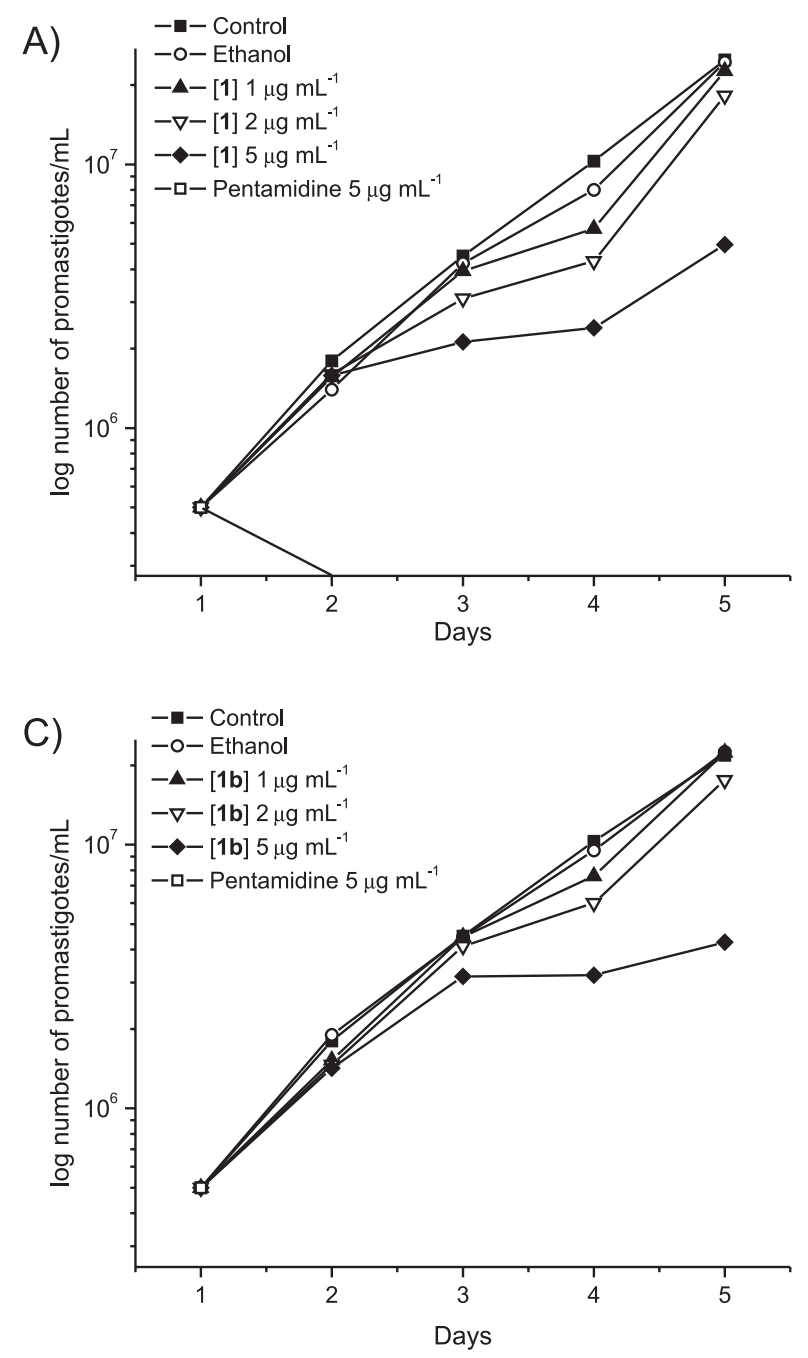

5 days. As shown in Figure 3A, after three days of culture, $5 \mu \mathrm{g} \mathrm{mL}{ }^{-1}$ of compound $\mathbf{1}$ inhibited cell growth. The number of promastigotes reduced at least $80 \%$ at the fifth day of culture if compared to both controls; the one untreated and the other treated with ethanol. The estimated $\mathrm{IC}_{50}$ of $\mathbf{1}$ for L. amazonensis promastigotes was $3.3 \mu \mathrm{g} \mathrm{mL}^{-1}(\mathrm{~F}=1889.8$; $\mathrm{P}<0.001)$. This compound has a potent effect of inhibiting the promastigote growth. The others concentrations ( 2 and $1 \mu \mathrm{g} \mathrm{mL}^{-1}$ ) inhibited the parasite growth in $27 \%$ and $9 \%$ respectively, if compared to untreated control or ethanoltreated control (Figure 3A).

As another approach, in order to assess the biological activity and verify whether the role of structural modifications could increase or decrease biological activity, synthetic derivatives from this triterpene 1 (Figure 1) were prepared as described in Experimental. Derivative 1a, which had the hydroxyl groups at $3 \beta$ and $16 \beta$ positions
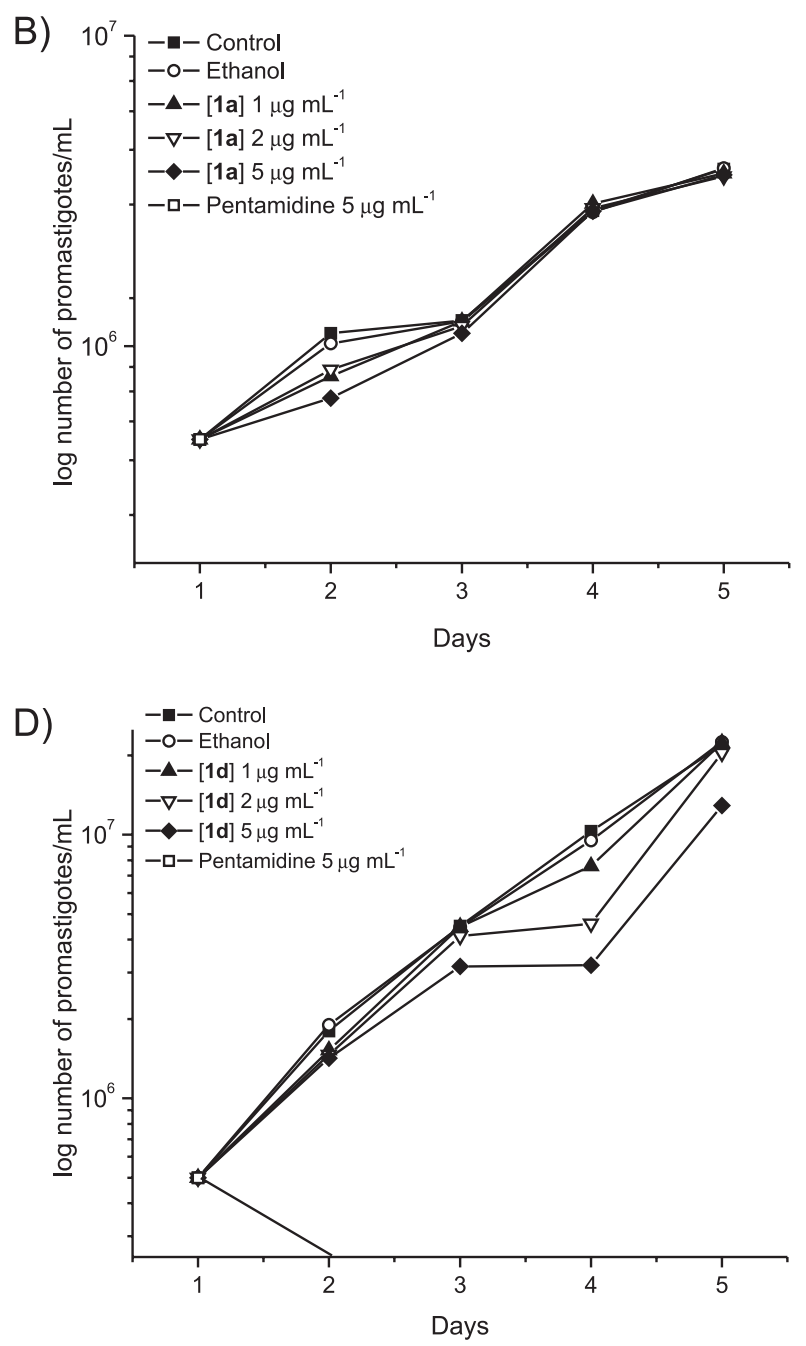

Figure 3. In vitro effect of triterpene $\mathbf{1}$ isolated from $C$. leprosum fruits and its synthetic derivatives $\mathbf{1 a - 1 d}$ on parasite growth. Representative inhibition growth curves of L. amazonensis promastigotes incubated with a range of concentrations of natural triterpene $\mathbf{1}$ (A), derivative $\mathbf{1 a}$ (B), derivative $\mathbf{1 b}(\mathrm{C})$, and derivative 1d (D) during 5 days at $24^{\circ} \mathrm{C}$. The promastigote growth inhibition was scored by counting of the viable parasites daily. The data shown is representative of at least five independent experiments. 
Table 2. Growth inhibition of L. amazonensis cultures by different concentrations of the triterpene $\mathbf{1}$ and its derivatives in vitro after five days

\begin{tabular}{|c|c|c|c|c|c|}
\hline & \multicolumn{5}{|c|}{ Promastigotes $\times 10^{5}$} \\
\hline & $1 \mu \mathrm{g} \mathrm{mL}^{-1}$ & $2 \mu \mathrm{g} \mathrm{mL}-1$ & $5 \mu \mathrm{g} \mathrm{mL} L^{-1}$ & $\mathrm{C}( \pm \mathrm{SE})$ & $\mathrm{EtOH}( \pm \mathrm{SE})$ \\
\hline Triterpene $\mathbf{1}$ & $226.8(\mathrm{a} 1)$ & $182.1(\mathrm{a} 2)$ & $49.6(\mathrm{a} 3)$ & $249.0 \pm 7.0$ & $244.2 \pm 7.6(4)$ \\
\hline Derivative 1a & 197.1 (b1) & $192.3(\mathrm{a} 1)$ & 202.3 (b1) & $190.7 \pm 3.9(1)$ & $190.7 \pm 8.5(1)$ \\
\hline Derivative $\mathbf{1 b}$ & 223.5 (a1) & $171.6(\mathrm{~b} 2)$ & $42.6(\mathrm{a} 3)$ & $218.3 \pm 6.8$ & $224.3 \pm 5.9(1)$ \\
\hline Derivative 1d & 222.6 (a1) & 203.8 (a2) & $129.0(\mathrm{~b} 3)$ & $218.3 \pm 6.9(1)$ & $224.3 \pm 5.9$ \\
\hline
\end{tabular}

$\mathrm{SE}=$ Standard Error; $\mathrm{C}=$ control without treatment; EtOH = Control with ethanol; Concentration $\left(\mu \mathrm{g} \mathrm{mL}^{-1}\right) \pm 3.75$ (SE) Two Way ANOVA, StudentNewman-Keuls (comparisons), $\mathrm{n}=8$. Different letters indicate significant $(\mathrm{P}<0.05)$ differences in a column and different numbers indicate significant differences in the same row.

replaced by acetyl, became inactive (Figure 3B). Derivative $\mathbf{1 b}$, that was trioxydated at positions $3 \beta, 6 \beta$ and $16 \beta$, had a similar antileishmanial activity if compared to the natural compound (Figure 3C). This derivative $\mathbf{1 b}$ at $5 \mu \mathrm{g} \mathrm{mL}^{-1}$ inhibited $80 \%$ of cell growth after 5 days of culture $(\mathrm{F}=3951.8 ; \mathrm{P}<0.001)$. Incubation with $2 \mu \mathrm{g} \mathrm{mL}^{-1}$ of $\mathbf{1 b}$ inhibited $21 \%$ of parasite growth and $1 \mu \mathrm{g} \mathrm{mL}^{-1}$ had no effect (Figure 3C). The estimated $\mathrm{IC}_{50}$ of derivative $\mathbf{1 b}$ for L. amazonensis promastigotes was $3.48 \mu \mathrm{g} \mathrm{mL}^{-1}$ similar of natural compound.

The derivative $1 \mathbf{d}$ presents a carbonyl group at position C-6, differently from the natural triterpene $\mathbf{1}$, which has a hydroxyl group at this position. This derivative 1d also inhibited L. amazonensis growth in vitro at the concentration of $5 \mu \mathrm{g} \mathrm{mL}^{-1}$, but the rate of inhibition was $41 \%(\mathrm{~F}=402.98 ; \mathrm{P}<0.001)$. This compound interfered only slightly with parasite growth in culture. At the concentration of $2 \mu \mathrm{g} \mathrm{mL}^{-1}$ it inhibited only of $6.5 \%$ of promastigote growth (Figure 3D). The estimated $\mathrm{IC}_{50}$ of derivative $1 \mathbf{d}$ was $5.9 \mu \mathrm{g} \mathrm{mL}^{-1}$.

The derivative $1 \mathrm{c}$ that was monooxydated at positions $6 \beta$ and had the hydroxyl groups at $3 \beta$ and $16 \beta$ positions replaced by acetyl was insoluble in ethanol, and therefore was not tested. The promastigotes incubated with ethanol (the vehicle used to dissolve the compounds $\mathbf{1}$ and $\mathbf{1 a - 1 d}$ ) showed growth rates equivalent to ones of the control cultures, indicating that the solvent/vehicle was not toxic to the parasite. The promastigote culture treated with ethanol showed no significant difference compared to control. On the other hand there was a significant difference between the rate growth of natural triterpene-treated parasites and derivative $\mathbf{1 a}$ and $\mathbf{1 d}$ treated parasites at $5 \mu \mathrm{g} \mathrm{mL}^{-1}(\mathrm{P}<0.05)$. At this concentration the triterpene $\mathbf{1}$ and the synthetic derivative $\mathbf{1 b}$ have the same leishmanicidal activity, inhibiting promastigote growth in a similar pattern (Table 2).

Structural modifications in natural compound $\mathbf{1}$ allowed us to conclude that the acetyl groups at positions $3 \beta$ and $16 \beta$ led to inactivation of the lupane. But, the replacement of hydroxyl groups by carbonyl groups did not significantly affect its activity, as shown in the results from derivatives $\mathbf{1 b}$ and $\mathbf{1 d}$. Compound $\mathbf{1}$ has $\mathrm{IC}_{50}=3.3 \mu \mathrm{g} \mathrm{mL}^{-1}$, derivative $\mathbf{1 b}$ has $\mathrm{IC}_{50}=3.48 \mu \mathrm{g} \mathrm{mL}^{-1}$ and $\mathbf{1 d}, \mathrm{IC}_{50}=5.8 \mu \mathrm{g} \mathrm{mL}^{-1}$.

Screening compounds with known toxic effects against Leishmania and no effect against host cell is a useful approach in enhancing our knowledge of the biological events that regulate the processes of growth arrest and death in this parasite. By the way EE, the natural compound $\mathbf{1}$ and synthetic derivatives 1a-1d were evaluated for their cytotoxicity against mouse peritoneal macrophages and none of them were cytotoxic to the mammalian cells by MTT assay (Table 3).

Table 3. Effect of EE, $\mathbf{1}$ and 1a-1d on the cell viability

\begin{tabular}{ll}
\hline Drug & O.D. ${ }_{540 \mathrm{~mm}}$ \\
\hline Control & $0.200 \pm 0.013$ \\
EE $25 \mu \mathrm{g} \mathrm{mL}^{-1}$ & $0.213 \pm 0.020$ \\
(1) $5 \mu \mathrm{g} \mathrm{mL}^{-1}$ & $0.223 \pm 0.019$ \\
(1a) $5 \mu \mathrm{g} \mathrm{mL}^{-1}$ & $0.205 \pm 0.019$ \\
(1b) $5 \mu \mathrm{g} \mathrm{mL}^{-1}$ & $0.217 \pm 0.030$ \\
(1d) $5 \mu \mathrm{g} \mathrm{mL}^{-1}$ & $0.206 \pm 0.018$ \\
\hline
\end{tabular}

Values are the mean \pm SE of the three independent experiments.

In conclusion, the $C$. leprosum Mart. contains a bioactive triterpene, which has a significant activity against L. amazonensis promastigotes. The results presented in this paper furtherly support a new activity of triterpene $\mathbf{1}$ isolated from the fruits of C. leprosum and two of its synthetic derivatives $\mathbf{1 b}$ and $\mathbf{1 d}$. The high pharmacological activity of $3 \beta, 6 \beta, 16 \beta$-trihydroxylup-20(29)-ene (1) from the C. leprosum fruits and the activity of the ethanolic extract on L. amazonensis promastigotes may be tools in further studies for the development of novel antileishmanial drugs.

\section{Supplementary Information}

Supplementary information is available free of charge at http://jbcs.sbq.org.br as a PDF file. 


\section{Acknowledgments}

This work was supported by Conselho Nacional de Desenvolvimento Científico e Tecnológico (CNPq).

\section{References}

1. http://www.who.int/leishmaniasis/burden/magnitude/burden magnitude/en/index.html accessed in May 2010.

2. Descoteaux, A.; Turco, S. J.; Biochim. Biophys. Acta 1999, 1455,341

3. Herwaldt, B. L.; Lancet 1999, 354, 1191.

4. Rosypal, A. C.; Troy, G. C.; Zajac, A. M.; Duncan, R. B.; Waki, K.; Chang, K. P.; Lindsay, D. S.; J. Eukaryot. Microbiol. 2003, 50,691 .

5. Goto, H.; Lindoso, J. A.; Expert Rev. Anti-Infect. Ther. 2010, $8,419$.

6. Romero, G. A.; Boelaert, M.; PLoS Negl. Trop. Dis. 2010, 4, 584.

7. Oullette, M.; Drummelsmith, J.; Papadopoulou, B.; Drug Resistance Updates 2004, 7, 257.

8. Estevez, Y.; Castillo, D.; Tangoa Pisango, M.; Arevalo, J.; Rojas, R.; Alban, J.; Deharo, E.; Bourdy, G.; Sauvain, M.; J. Ethnopharmacol. 2007, 114, 254.

9. Osório, E.; Arango, G. J.; Jimenez, N.; Alzate, F.; Ruiz, G.; Gutiérrez, D.; Paco, M. A.; Gimenez, A.; Robledo, S.; J. Ethnopharmacol. 2007, 111, 630.

10. Izumi, E.; Morello, L. G.; Ueda-Nakamura, T.; Yamada-Ogatta, S. F.; Dias-Filho, B. P.; Cortez, D. A. G.; Ferreira, I. C. P.; Morgado-Diaz, J. A.; Nakamura, C. V.; Exp. Parasitol. 2008, $118,324$.

11. Zhai, L.; Chen, M.; Blom, J.; Theander, T. G.; Christensen, S. B.; Arsalan, K.; J. Antimicrob. Chemother. 1999, 43, 793.

12. Tempone, A. G.; Borborema, S. E.; de Andrade, H. F. Jr.; de Amorim Gualda, N. C.; Yogi, A.; Carvalho, C. S.; Bachiega, D.; Lupo, F. N.; Bonotto, S. V.; Fischer, D. C.; Phytomedicine 2005, 12, 382.

13. Grandic, S. R.; Fourneau, C.; Laurens, A.; Bories, C.; Hocquemiller, R.; Loiseau, P. M.; Biomed. Pharmacother. 2004, 58, 388

14. Özipek, M.; Dónmez, A. A.; Çalis, I.; Brun, R.; Rüedi, P.; Tasdemir, D.; Phytochemistry 2005, 66, 1168.

15. Eloff, J. N.; Katerere, D. R.; McGaw, L. J.; J. Ethnopharmacol. 2008, 119, 686 .

16. McGaw, L. J.; Rabe, T.; Sparg, S. G.; Jager, A. K.; Eloff, J. N.; Staden van, J.; J. Ethnopharmacol. 2001, 75, 45.

17. Cirla, A.; Mann, J.; Nat. Prod. Rep. 2003, 20, 558.

18. Young, S. L.; Chaplin, D. J.; Expert Opin. Investing Drugs 2004, $13,1171$.

19. Masoko, P.; Mdee, L. K.; Mampuru, L. J.; Eloff, J. N.; Nat. Prod. Res. 2008, 22, 1074.
20. Ali, H.; Konig, G. M.; Khalid, S. A.; Kright, A. D.; Kaminsky, R.; J. Ethnopharmacol. 2002, 83, 219.

21. Martini, N. D.; Katerere, D. R. P.; Eloff, J. N.; J. Ethnopharmacol. 2004, 93, 207.

22. Asres, K.; Bucar, F.; Knauder, E.; Yardley, V.; Kendrick, H.; Croft, S. L.; Phytother. Res. 2001, 15, 613.

23. Ancolio, C.; Azas, N.; Mahiou, V.; Olliver, E.; Giorgio, C.; Keita, A.; Timon-Davi, P.; Balnsard, G.; Phytother. Res. 2002, $19,646$.

24. Griggs, J.; Metcalfe, J. C.; Hesketh, R.; Lancet Oncol. 2001, 2 , 82.

25. Nam, N. H.; Curr. Med. Chem. 2003, 10, 1697.

26. Nabha, S. M.; Wall, N. R.; Mohammed, R. M.; Pettit, G. R.; AL-Katid, A. M.; Anticancer Drugs 2000, 11, 385.

27. Lira, S. R. D.; Almeida, R. N.; Almeida, F. R. C.; Oliveira, F. S.; Duarte, J. C.; Pharm. Biol. 2002, 40, 213.

28. Adnyana, I. K.; Tezuka, Y.; Baskota, A. H.; Tran, K. O.; Kadota, S.; J. Nat. Prod. 2001, 64, 360.

29. Facundo, V. A.; Andrade, C. H. S.; Silveira, E. R.; Braz-Filho, R.; Huford, C. D.; Phytochemistry 1993, 32, 411.

30. Agnew, P.; Holzmuller, P.; Michalakis, Y.; Sereno, D.; Lemesre, J. L.; Renaud, F.; Antimicrob. Agents Chemother. 2001, 45, 1928.

31. Mosmann, T.; J. Immunol. Methods 1983, 65, 55.

32. Nunes, P. H.; Cavalcanti, P. M.; Galvão, S. M.; Martins, M. C.; Pharmazie 2009, 64, 58.

33. Facundo, V. A.; Rios, K. A.; Medeiros, C. M.; Militão, J. S. L. T.; Miranda, A. L. P.; Epifanio, R. A.; Carvalho, M. P.; Andrade, A. T.; Pinto, A. C.; Rezende, C. M.; J. Braz. Chem. Soc. 2005, 16,1309

34. Pietrovski, E. F.; Rosa, K. A; Facundo, V. A; Rios, K.; Marques, M. C. A.; Santos, A. R. S.; Pharmacol., Biochem. Behav. 2006, $83,90$.

35. Choisy, M.; Hide, M.; Bañuls, A. L.; Guégan, J. F.; Trends Microbiol. 2004, 12, 534.

36. Messaritakis, I.; Mazeris, A.; Koutala, E.; Antoniou, M.; Exp. Parasitol. 2010, 125, 384.

37. Masika, P. J.; Afolayan, A. J.; J. Ethnopharmacol. 2002, 83, 129.

38. Katerere, D. R.; Gray, A. I. Nash, R. J.; Waigh, R. D.; Phytochemistry 2003, 63, 81.

39. Asres, K.; Bucar, F.; Knauder, E.; Yardley, V.; Kendrick, H; Croft, S. L.; Phytother. Res. 2001, 15, 613.

40. Fyrquist, P.; Mwasumbi, L.; Haeggstrom, C.; Vourela, H.; Hiltunem, R.; Vurela, P.; J. Ethnopharmacol. 2002, 79, 169.

41. Rogers, C. B.; Phytochemistry 1998, 49, 2069.

42. Ferrea, G.; Canessa, A.; Sampietro, F.; Cruciani, M.; Romussi, G.; Bassetti, D.; Antiviral Res. 1993, 21, 317.

Submitted: March 10, 2009 Published online: February 8, 2011 


\title{
Activity of the Lupane Isolated from Combretum leprosum against Leishmania amazonensis Promastigotes
}

\author{
Carolina B. G. Teles, ${ }^{a}$ Leandro S. Moreira, ${ }^{b}$ Alexandre de A. E. Silva, ${ }^{a, b}$ Valdir A. Facundo, ${ }^{b}$ \\ Juliana P. Zuliani, ${ }^{a, b}$ Rodrigo G. Stábeli ${ }^{a, c}$ and Izaltina Silva-Jardim*,a
}

a Instituto de Pesquisas em Patologias Tropicais de Rondônia-IPEPATRO, Rua da Beira, 7671,

BR 364, km 3,5, 76812-245 Porto Velho-RO, Brazil

${ }^{b}$ Universidade Federal de Rondônia, BR 364, km 9,5, 76800-000 Porto Velho-RO, Brazil

${ }^{c}$ Fiocruz do Noroeste do Brasil, FIOCRUZ-RO, Rua da Beira, 7671, BR 364, km 3,5,

76812-245 Porto Velho-RO, Brazil

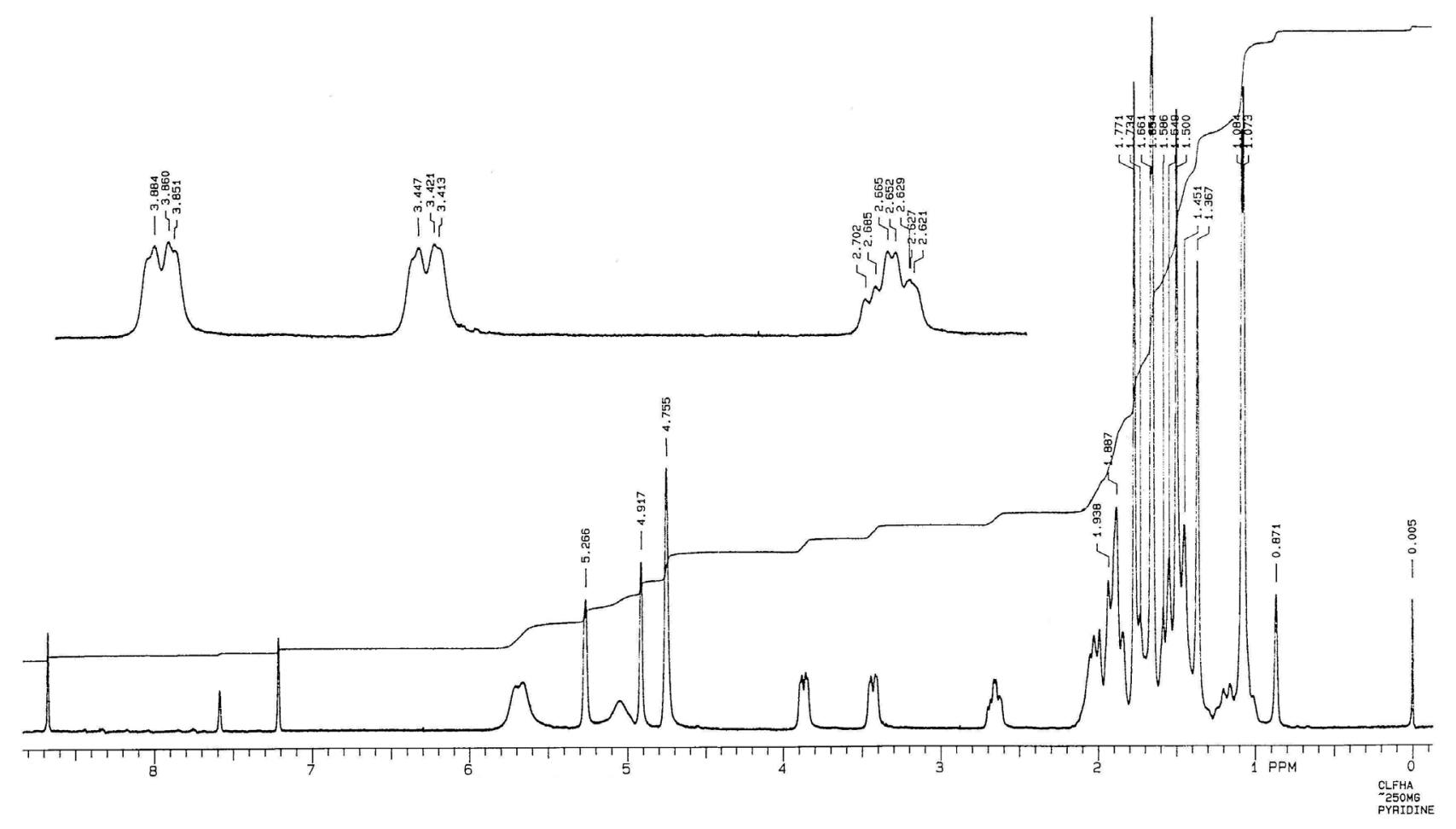

Figure S1. ${ }^{1} \mathrm{H}$ NMR spectrum of $\mathbf{1}$. 


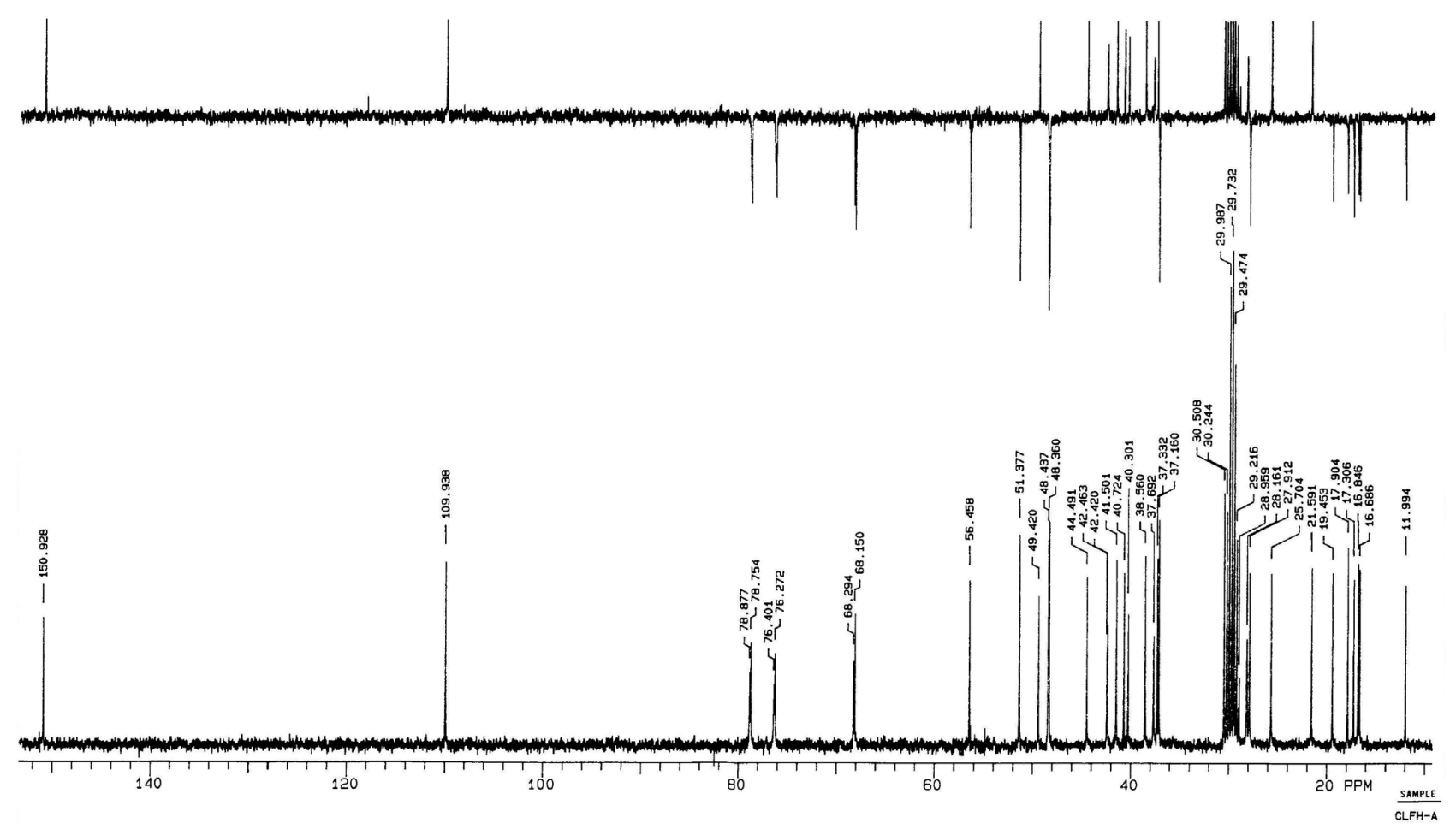

Figure S2. ${ }^{13} \mathrm{C}$ NMR spectrum of $\mathbf{1}$.

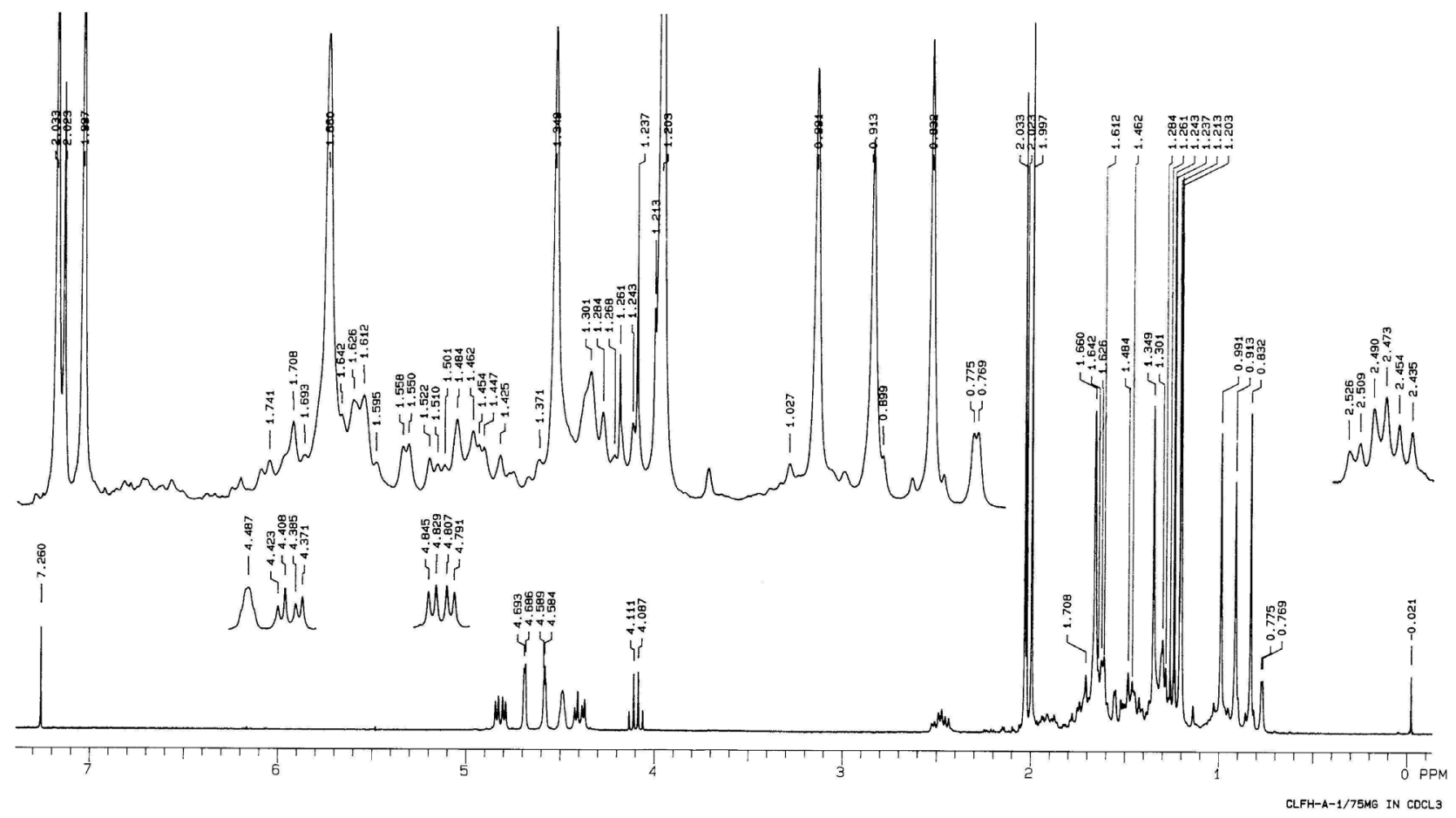

Figure S3. ${ }^{1} \mathrm{H}$ NMR spectrum of $\mathbf{1 a}$. 


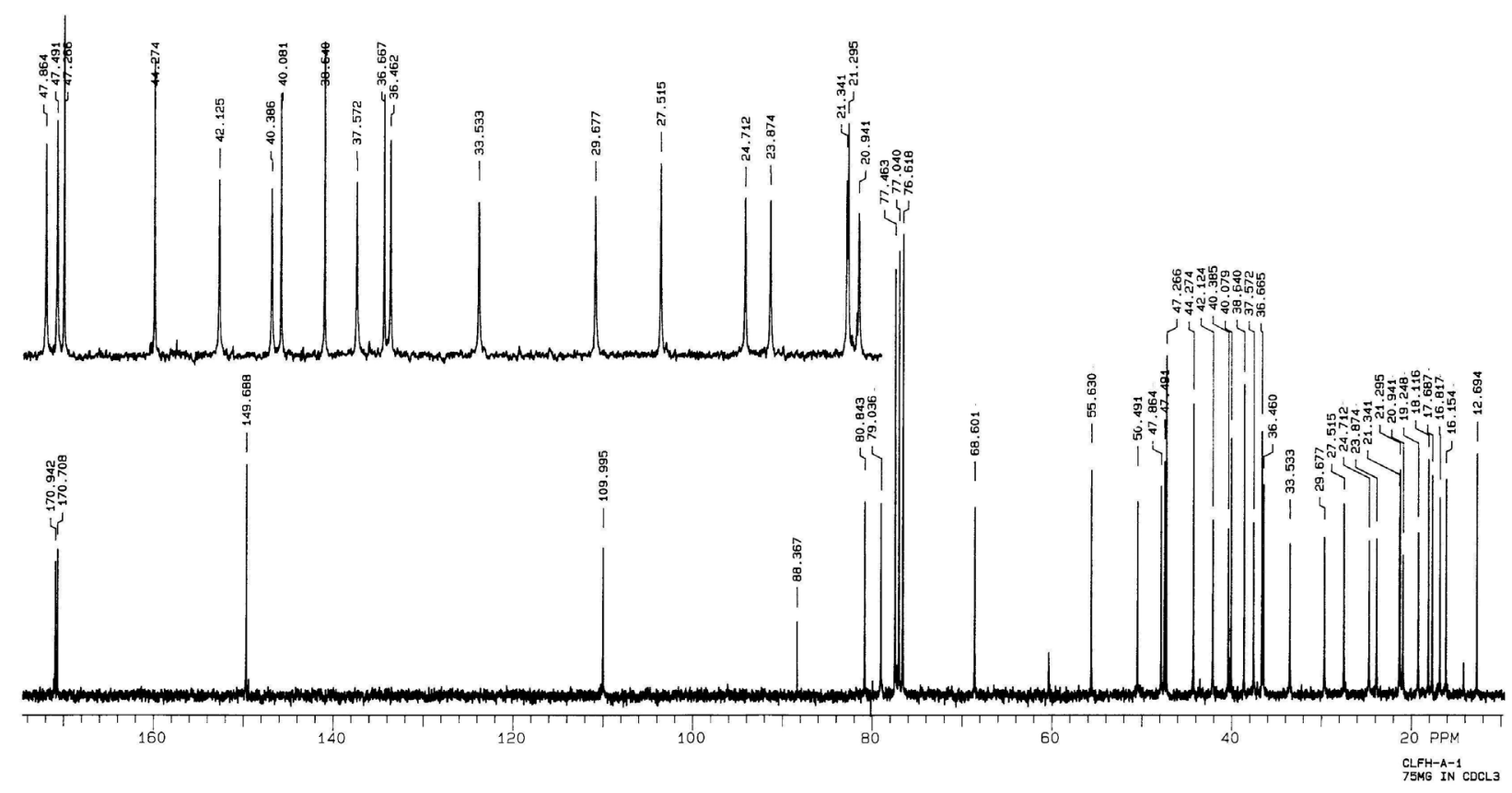

Figure S4. ${ }^{13} \mathrm{C}$ NMR spectrum of $\mathbf{1 a}$.

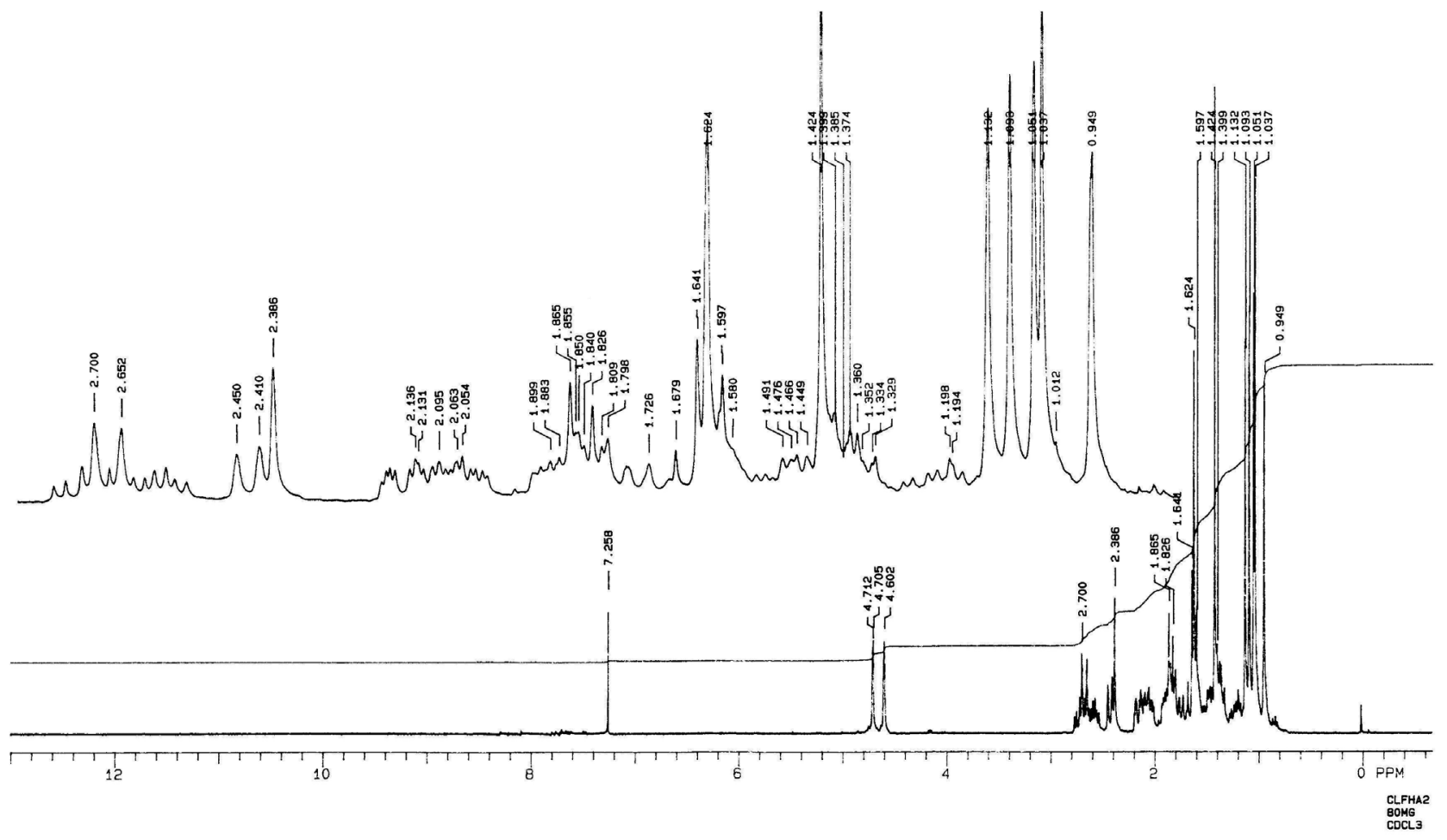

Figure S5. ${ }^{1} \mathrm{H}$ NMR spectrum of $\mathbf{1 b}$. 


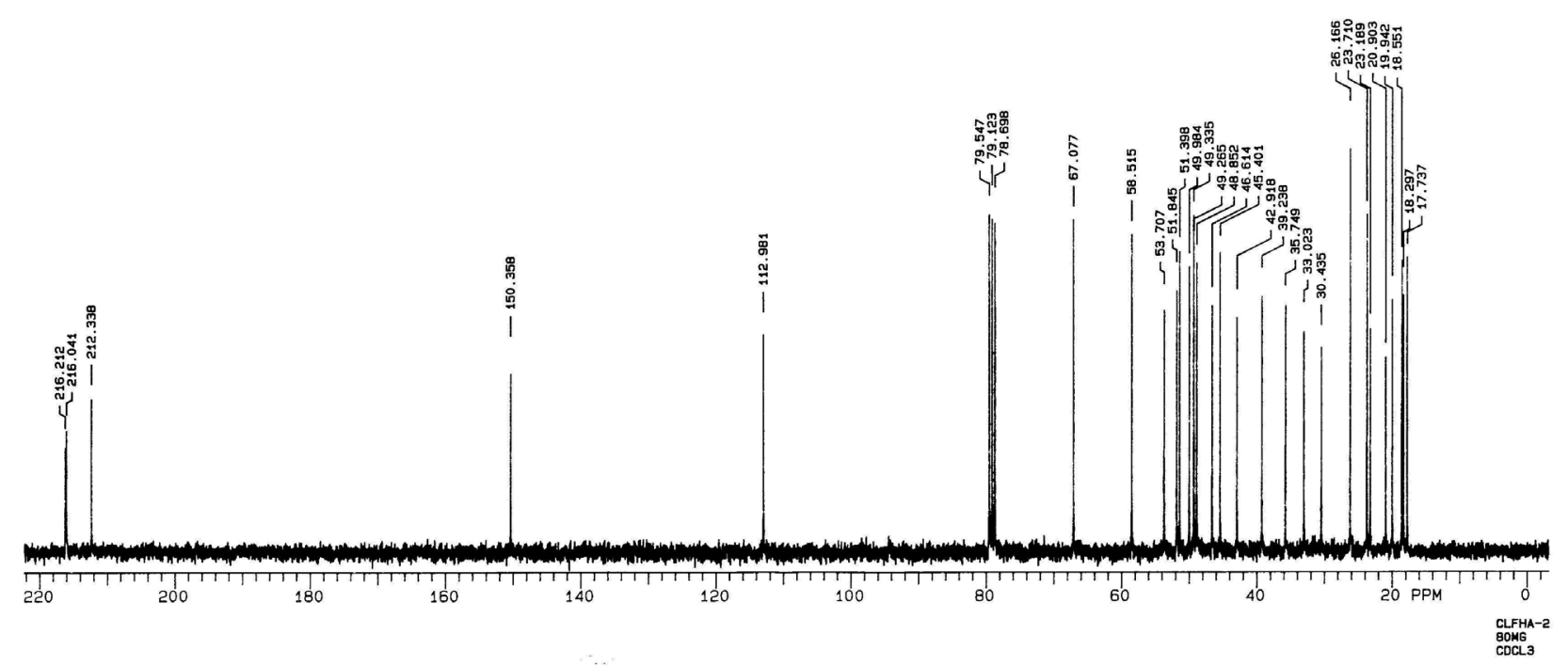

Figure S6. ${ }^{13} \mathrm{C}$ NMR spectrum of $\mathbf{1 b}$.

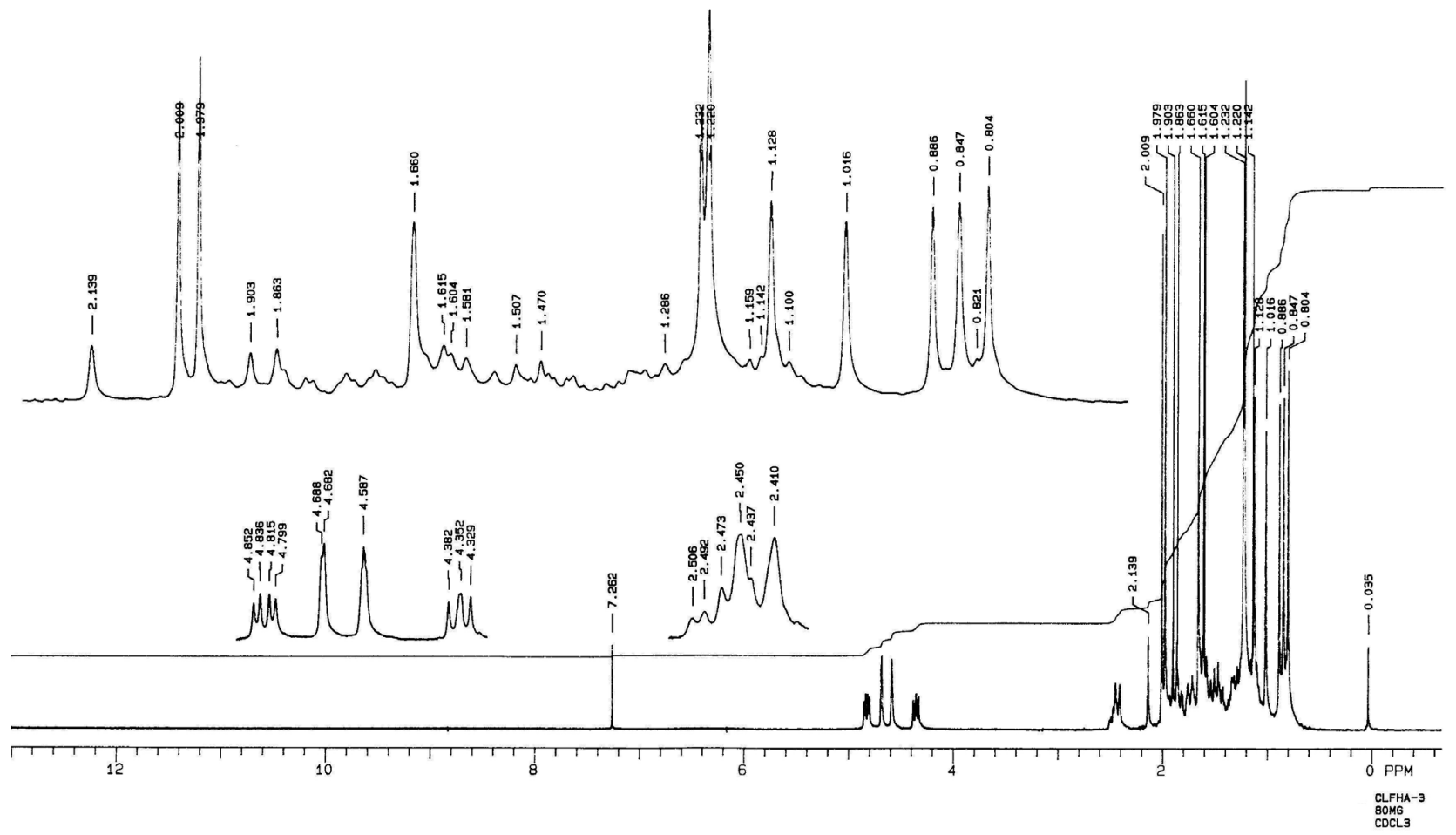

Figure S7. ${ }^{1} \mathrm{H}$ NMR spectrum of $\mathbf{1 c}$. 

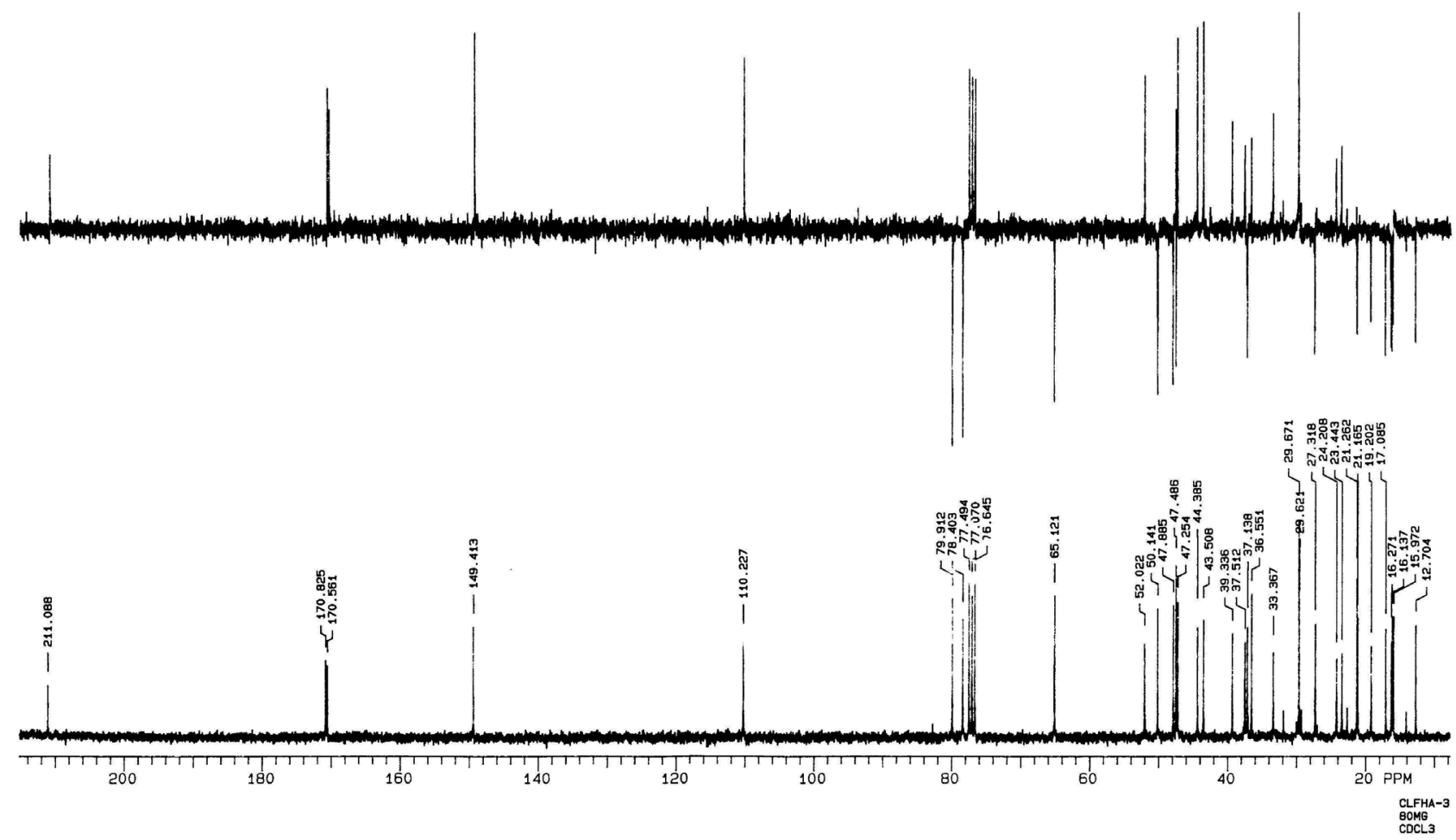

Figure S8. ${ }^{13} \mathrm{C}$ NMR spectrum of 1c.

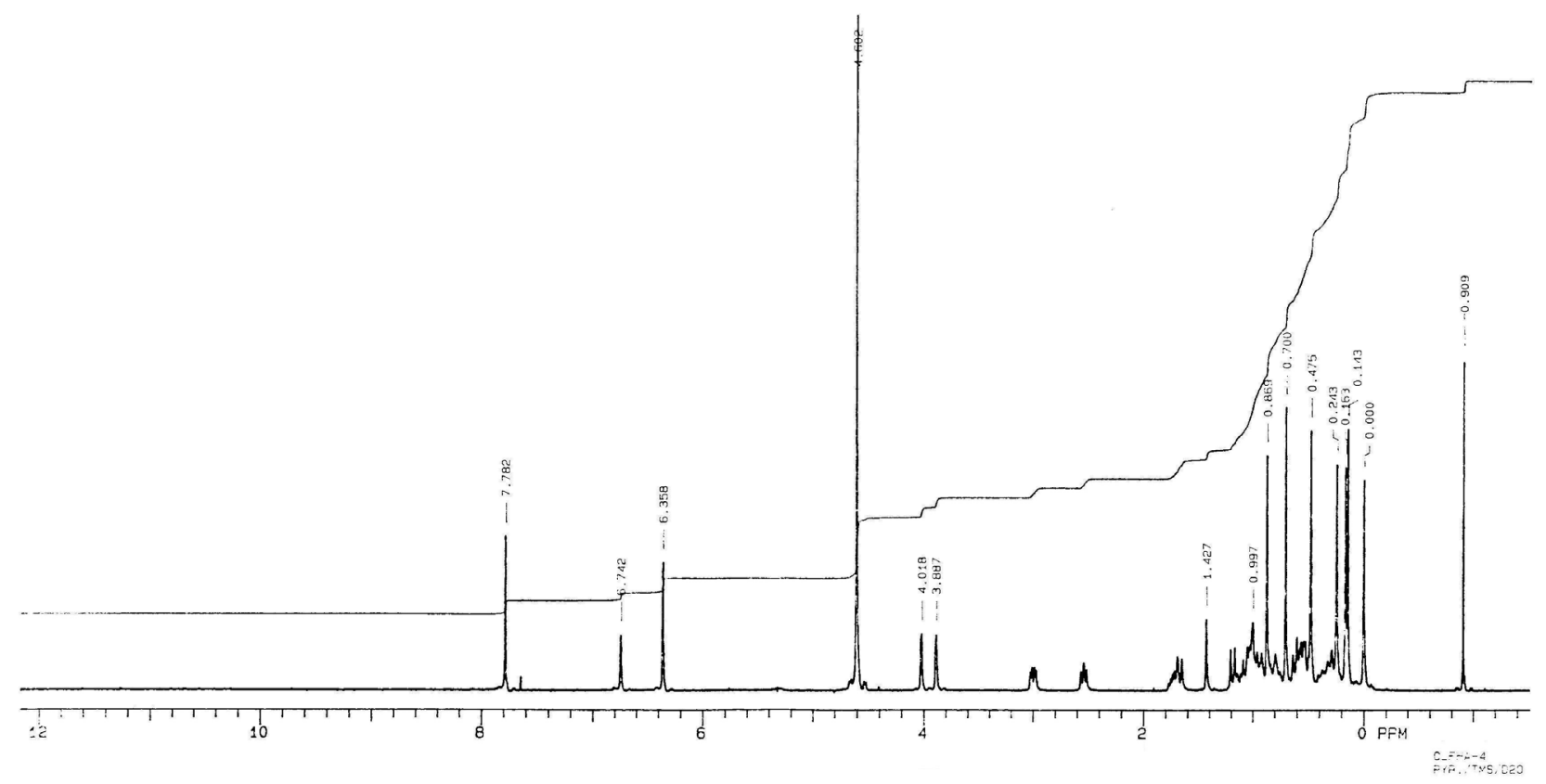

Figure S9. ${ }^{1} \mathrm{H}$ NMR spectrum of $\mathbf{1 d}$. 


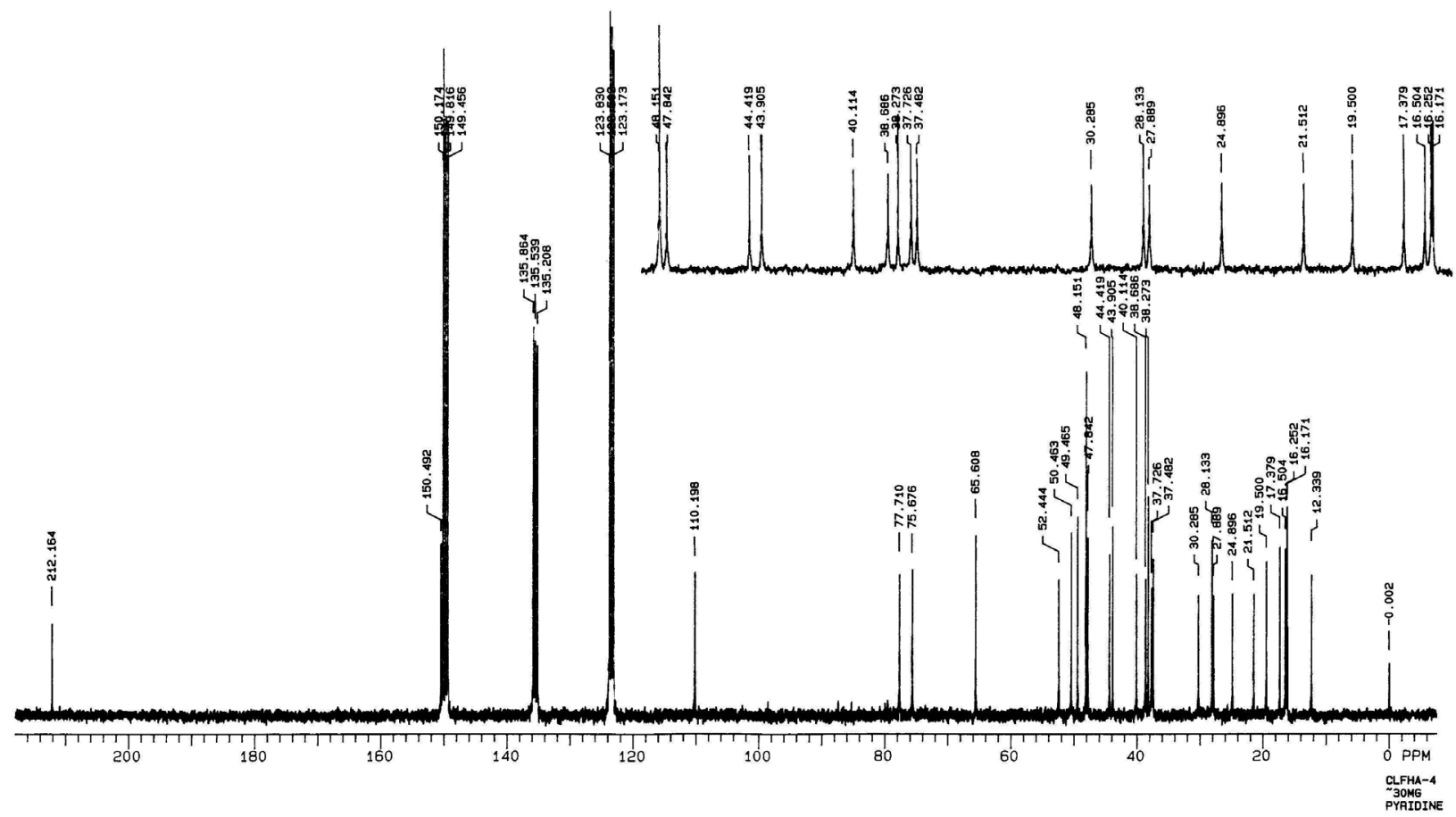

Figure S10. ${ }^{13} \mathrm{C}$ NMR spectrum of $\mathbf{1 d}$. 